\title{
PELATIHAN IT MELALUI PEMBUATAN E-MODUL MATEMATIKA BAGI GURU MATEMATIKA SMK KABUPATEN MALANG
}

\author{
Retno Marsitin ${ }^{1)}$, Nyamik Rahayu Sesanti ${ }^{2)}$, Rini Agustina ${ }^{3)}$ \\ ${ }^{1)}$ Fakultas Sains dan Teknologi, Universitas Kanjuruhan Malang \\ email: ${ }^{1)}$ mars_retno@unikama.ac.id \\ ${ }^{2)}$ Fakultas Keguruan dan Ilmu Pendidikan, Universitas Kanjuruhan Malang \\ email: ${ }^{2}$ nyamik@unikama.ac.id \\ ${ }^{3)}$ Fakultas Sains dan Teknologi, Universitas Kanjuruhan Malang \\ email: ${ }^{3)}$ ryfany@gmail.com
}

\begin{abstract}
Abstrak
Kualitas pembelajaran matematika tampak dari peran guru matematika yang berkompeten dalam pembelajaran yang akhirnya berdampak pada kualitas peserta didiknya. Salah satu upaya dalam meningkatkan kualitas pembelajaran matematika dengan memiliki ketrampilan Informasi Teknplogi (IT). Kegiatan Program Kemitraan Masyarakat bertujuan untuk meningkatkan ketrampilan IT bagi guru matematika SMK Kabupaten Malang melalui pembuatan e-modul dalam pembelajaran matematika. Teknologi dalam pembelajaran melalui Elektronik Modul (E-Modul). E-Modul merupakan modul pembelajaran menggunakan software diantaranya software sigil. E-Modul sangat berperan dalam pembelajaran matematika. Jenis pelaksanaan program kemitraan masyarakat berbentuk pelatihan pembuatan e-modul matematika. Metode dalam kegiatan pembuatan e-modul matematika meliputi: pendampingan menginstal software sigil, memberikan materi dan dialog interaktif dengan demonstrasi/simulasi/praktik dilanjutkan presenasi dan evaluasi serta dilanjutkan desiminasi dalam kegiatan Musyawarah Guru Mata Pelajaran (MGMP) Matematika SMK Kabupaten Malang. Hasil kegiatan program kemitraan masyarakat berupa produk modul dan e-modul pembelaran matematika. Kegiatan program kemitraan masyarakat memperoleh respon tanggapan yang positif dari guru matematika SMK.
\end{abstract}

Kata kunci: Peatihan IT, pembuatan e-modul, guru matematika SMK

\section{PENDAHULUAN}

\section{Analisis Mitra}

Pembelajaran matematika di sekolah sudah saatnya bergeser menjadi pembelajaran matematika yang memanfaatkan teknologi, sehingga guru matematika perlu melakukan inovasi pembelajaran, khususnya pembelajaran matematika SMK. Guru Matematika SMK masih jarang melakukan inovasi pembelajaran yang memanfaatkan teknologi dengan menggunakan aplikasi software dalam pembelajaran matematika. Guru matematika SMK masih sedikit kurang dari limapuluh persen yang menerapkan pembelajaran matematika dengan memanfaatkan teknologi dalam menyampaikan materi pembelajaran. Berkenaan dengan hal tersebut maka guru matematika SMK harus melek IT agar tidak ketinggalan zaman.

Kegiatan program kemitraan masyarakat dengan dua mitra yaitu SMK Negeri 1 Gedangan dan SMK PGRI Singosari. SMK Negeri 1 Gedangan Kabupaten Malang terletak $\pm 30 \mathrm{~km}$ dari Kota Malang dengan alamat di Jl Sumberejo Kecamatan
Gedangan Kabupaten Malang Propinsi Propinsi Jawa Timur. SMK Negeri 1 Gedangan Kabupaten Malang merupakan sekolah menengah kejuruan dengan bidang keahlian yaitu multimedia, teknik kendaraan ringan, jasa boga, busana batik dan akuntansi. SMK Negeri 1 Gedangan, di Kabupaten Malang juga terdapat SMK PGRI Singosari Kabupaten Malang dengan alamat di Jl. Morotanjek no. 2016 Pagentan, Kecamatan Singsosari Kabupaten Malang Propinsi Propinsi Jawa Timur. SMK PGRI Singosari Kabupaten Malang merupakan sekolah menengah kejuruan dengan bidang keahlian yaitu teknik kendaraan ringan, teknik sepeda motor, teknik otomasi industri, teknik elektronika industri, teknik rekayasa perangkat lunak, teknik komputer jaringan.

Hasil informasi dari masing-masing sekolah bahwa guru-guru matematika telah tersertifikasi. Hal ini menunjukkan bahwa guru matematika telah dianggap sebagai pendidik professional. Guru-guru matematika juga terlibat aktif dalam kegiatan Musyawarah Guru Mata Pelajaran (MGMP) matematika SMK Kabupaten Malang Propinsi Jawa 
Timur, yang minimal dilakukan satu bulan sekali. Kegiatan dalam MGMP secara umum lebih terfokus pada pembahasan kurikum 2013, pembuatan soal lokal, pembahasan soal ujian dan ujian nasiobnal serta tryout soal-soal. Tampak bahwa kegiatan MGMP masih jarang membahas aspek yang terkait langsung dengan pembelajaran di kelas misalnya pembelajaran yang dihadapi guru di kelas, metode pembelajaran yang terbaru maupun strategi penilaian yang baik dan positif dalam menilai kemampuan peserta didik. Aktivas MGMP belum optimal dalam mengembangkan kompetensi guru matematika SMK. Kegiatan MGMP belum mengembangkan metode pembelajaran yang kolaboratif di kelas maupun di luar kelas pada guru matematika SMK, sehingga MGMP belum dapat membantu guru matematika SMK dalam berbagi ide tentang fakta, rencana, materi dan bahan ajar matematika. Wawasan dan pengetahuan guru matematika SMK untuk mewujudkan pembelajaran yang efektif, efisien dan menyenangkan belum maksimal. Kegiatan-kegiatan untuk meningkatkan kemampuan juga guru telah diupayakan oleh Diknas Pendidikan dengan menyelenggarakan berbagai kegaiatan seminar atau pelatihan terutama yang terkait dengan pembelajaran berbasis teknologi. Namun demikian, tidak semua guru bisa mengikuti kegiatan tersebut karena tidak semua dikirim. Guru yang dikirim mewakili sekolah bersifat bergantian dalam mengikuti kegiatan tersebut, juga dikarenakan keterbatasan kuota yang diberikan oleh lembaga terkait terbatas.

Hal ini yang lebih menarik untuk dicermati yaitu terkait dengan realita lapangan bahwa mayoritas guru matematika masih jarang yang menerapkan pembelajaran dengan memanfaatkan teknologi. Beban mengajar guru matematika yang overload dan memiliki tugas tambahan selain mengajar sehingga menghambat guru dalam melakukan inovasi dalam pembelajaran berbasis teknologi. Respon guru matematika SMK terhadap kemajuan teknologi informasi perlu ditingkatkan, karena kemajuan teknologi informasi yang demikian pesat dapat dimanfaatkan dalam pembelajaran. Padahal adanya kurikulum SMK yang mewajibkan peserta didik melaksanakan Praktik Kerja Industri (PRAKERIN), mengakibatkan tatap muka pelajaran matematika berkurang, sehingga membutuhkan interaksi pembelajaran matematika yang efektif untuk peserta didik yang sedang melaksanakan PRAKERIN. Selain itu, hampir semua peserta didik memiliki fasilitas yang bisa dipergunakan sebagai penunjang pembelajaran ketika peserta didik melaksanakan PRAKERIN, misalkan HP Android dan Laptop. Selama ini fasilitas tersebut kurang dimanfaatkan oleh guru mtematika SMK agar peserta didik belajar melalui media yang mereka miliki dan berpengalaman dalam pembelajaran berbasis teknologi.

Mencermati situasi yang demikian, maka bersama dua mitra sekolah yaitu SMK Negeri 1 Gedangan dan SMK PGRI Singosari bersepekat untuk mengatasi permasalahan dengan memberikan program kemitraan masyarakat dengan memberikan pelatihan IT melalui pembuatan modul dan e-modul guru matematika SMK Kabupaten Malang Propinsi Jawa Timur.

\section{Permasalahan Mitra}

Mengacu pada paparan analisis situasi diatas, permasalahan yang dihadapi guru-guru matematika SMK Kabupaten Malang Propinsi Jawa Timur, yaitu:

a. Guru Matematika SMK Kabupaten Malang Propinsi Jawa Timur masih perlu ditingkatkan kualitasnya dengan mengkaji ulang pembelajaran yang selama ini diterapkan di kelas. Aktifitas untuk meningkatkan kemampuannya sebagai tenaga pendidik jarang dilakukan. Diskusi aktif juga belum dilakukan dalam meningkatkan kualitas pembelajaran.

b. Guru Matematika SMK Kabupaten Malang Propinsi Jawa Timur yang terlibat aktif dalam kegiatan MGMP Kabupaten Malang belum maksimal dalam mengembangkan kompetensinya sebagai tenaga pendidik. Hal ini tampak pada sebagian besar masih menggunakan buku cetak yang ada sehingga masih belum kreatif dalam membuat bahan ajar yang berorientasi pada karakteristik peserta didik.

c. Guru Matematika SMK Kabupaten Malang Propinsi Jawa Timur masih jarang yang menerapkan pembelajaran dengan 
memanfaatkan teknologi. Padahal adanya kurikulum SMK yang mewajibkan peserta didik melaksanakan praktik kerja industri, mengakibatkan tatap muka pelajaran matematika berkurang, sehingga membutuhkan interaksi pembelajaran matematika yang efektif untuk peserta didik yang sedang praktik kerja industri. Selain itu, hampir semua peserta didik memiliki fasilitas yang bisa dipergunakan sebagai penunjang pembelajaran ketika peserta didik melaksanakan praktik kerja industri, misalkan HP Android dan Laptop. Selama ini fasilitas tersebut kurang dimanfaatkan oleh guru matematika SMK dalam pembelajaran.

d. Guru Matematika SMK Kabupaten Malang Propinsi Jawa Timur masih jarang melakukan inovasi pembelajaran yang memanfaatkan teknologi, padahal pembelajaran matematika di sekolah sudah bergeser menjadi pembelajaran matematika yang mnggunakan teknologi. Guru Matematika perlu melakukan inovasi pembelajaran dengan menggunakan teknologi. Hal ini karena pembelajaran dengan teknologi belum maksimal dikenal dikalangan guru matematika SMK, misalnya software sigil.

\section{Solusi yang Ditawarkan}

Permasalahan mitra yang telah dipaparkan, sangat perlu diupayakan pemecahan permasalahan yang dihadapi oleh SMK Negeri 1 Gedangan dan SMK PGRI Singosari. Upaya pemecahaan permasalahan dengan memberikan solusi yang diusulkan dalan Program Kemitraan Masyarakat (PKM). Adapun solusi yang ditawarkan yaitu: pelatihan pembuatan pembuatan bahan ajar berupa modul pembelajaran matematika SMK dengan target peningkatan pemahaman membuat modul matematika SMK dan pelatihan pembuatan bahan ajar berupa e-modul pembelajaran matematika SMK dengan target Peningkatan pemahaman membuat emodul matematika SMK serta pendampingan emodul dengan software sigil.

Kegiatan Program Kemitraan Masyarakat (PKM) menekankan pada penerapan ilmu pengetahuan dan teknologi guna meningkatkan kompetensi guru matematika SMK Negeri 1 Gedangan dan SMK PGRI Singosari melalui pelaksanaan pelatihan pembuatan e-modul pembelajaran matematika SMK. Produk kegiatan ini berupa modul dan e-modul pembelajaran matematika SMK.

\section{METODE KEGIATAN}

Metode yang ditawarkan untuk menyelesaikan masalah mitra yaitu dengan menyelenggarakan workshop dan pelatihan juga pendampingan terkait pembuatan bahan ajar berupa modul dan elektronik modul (e-modul) pembelajaran matematika SMK. Selanjutnya pembentukan focus group discussion yang aktif dan dinamis dan penyelenggaraan konferensi guru untuk mempresentasikan hasil modul dan e-modul pembelajaran matematika SMK oleh para guru yang terlibat dalam program ini, sehinga modul dan e-modul pembelajaran matematika SMK layak digunakan dalam pembelajaran matematika.

\section{Langkah-langkah Solusi atas Permasalahan Mitra}

Langkah-langkah praktis yang dilakukan sebagai solusi atas permasalahan mitra pada program kemitraan masyarakat guru matematika SMK Kabupaten Malang yaitu:

a. Workshop terkait pembuatan bahan ajar berupa modul pembelajaran matematika SMK. Pelaksanakan workshop ini dengan diharapkan guru matematika SMK memahami tentang pembuatan bahan ajar berupa modul pembelajaran matematika SMK dan mampu membuat bahan ajar berupa modul pembelajaran matematika SMK. Pada workshop ini, disampaikan tentang definisi dan jenis-jenis bahan ajar, bahan ajar yang berdasarkan karakteristik peserta didik dan prinsip-prinsip pembuatan bahan ajar. Guru juga dibekali dengan pengetahuan tentang bahan ajar yang berupa modul pembelajaran, perbedaan modul pembelajaran dengan bahan ajar yang lain, modul, modul pembelajaran dengan pendekatan teori tertentu dan prinsip-prinsip dalam pembuatan modul pembelajaran. Selanjutnya, diadakan diskusi dan tanya jawab antara guru matematika dan pemateri. 
b. Workshop pembuatan bahan ajar berbentuk emodul pembelajaran matematika SMK. Pada workshop ini akan disampaikan manfaat dari emodul pembelajaran matematika SMK dan langka-langkah pembuatan e-modul. Guru dibekali dengan pengetahuan tentang software emodul. Selanjutnya, diadakan diskusi dan tanya jawab.

c. Pelatihan dan pendampingan guru dalam pembuatan bahan ajar berbentuk e-modul pembelajaran matematika SMK. Tim pengusul mendampingi guru dalam pembuatan e-modul. Hasil uji coba di konsultasikan ke tim pengusul sebagai bahan revisi dari e-modul. Target dari pendampingan ini adalah terbentuknya e-modul dari masing-masing guru.

d. Pendampingan pada pelaksanaan focus group discussion yang dilakukan setiap empat minggu sekali. Kegiatan ini dilakukan secara berkesinambungan dengan harapan guru segera memperoleh feedback dari guru lain maupun tim pengusul sehingga kegiatan lebih terarah.

e. Pendampingan pada kegiatan desiminasi dalam konferensi guru dengan mempresentasikan hasil modul dan e-modul pembelajaran matematika SMK yang telah dihasilkan agar mendapatkan masukan, saran dan kritik dari guru lain. Hasil dari kegiatan ini adalah modul dan e-modul pembelajaran matematika SMK yang layak digunakan dalam pembelajaran.

\section{Partisipasi Mitra dalam Pelaksanaan Program}

Partisipasi mitra dalam pelaksanaan program kemitraan masyarakat dalam menentukan keberhasilan dan keberlanjutan program meliputi:

a. Aplikasi software sigil dalam e-modul pada pembelajaran matematika SMK.

b. Pembuatan materi pembelajaran dalam modul matematika

c. Pembuatan e-modul pembelajaran matematika SMK dengan software sigil sebagai bentuk peningkatan profesionalisme guru.

d. Pelaksanaan Focus Group Discussion.

e. Pelaksanaan diseminasi dalam konferensi guru dengan presentasi hasil materi pembelajaran modul dan e-modul pembelajaran matematika SMK dengan software sigil.

\section{HASIL DAN PEMBAHASAN}

Kegiatan program kemitraan masyarakat pada pelatihan IT melalui pembuatan e-modul guru matematika SMK kabupaten Malang dilakukan dengan dua mitra yaitu SMKN 1 Gedangan dan SMK PGRI Singosari kabupaten Malang. Kegiatan pelatihan pembuatan modul dengan materi yang meliputi: penyampaian pentingnya modul dalam pembelajaran matematika, pengerian modul dengan pendapat beberapan ahli, langkah penting dalam membuat modul, pendekatan pembelajaran dalm membuat modul agar modul menarik bagi peserta didik dan selanjutnya memberikan motivasi agar guru lebih kreatif dalam membuat modul. Ketercapai kegiatan pelatihan pembuatan modul matematika yaitu modul matematika yang dibuat oleh guru matematika SMKN 1 Gedangan dan SMK PGRI Singosari kabupaten Malang.

Kegiatan selanjutnya dengan pelatihan pembuatan e-modul. Pembuatan e-modul dengan materi meliputi: penyampaian penting e-modul dalam pembelajaran terutama pembelajaran matematika, pengertian e-modul dengan pendapat beberapa ahli, langkah penting dalam pembuatan emodul, memberikan pendampingan dalam menginstal aplikasi sigil sebagai software pembuatan e-modul dan langkah-langkah menggunakan aplikasi sigil. Modul yang telah dikerjakan sebelumnya kemudian diubah dalam bentuk e-modul dan dilakukan pendampingan dalam pembuatan e-modul dengan aplikasi sigil. Hasil emodul akan bisa terlihat di HP Android sehingga materi dalam modul terbaca dalam HP Android masing-masing guru matematika SMK. Pembuatan e-modul dengan aplikasi sigil didampingi dari ahli dalam bidang IT agar mempermudah instal sigil dan pemahaman terkait sigil. Hal ini sesuai dengan pendapat (Zuriah, Sunaryo \& Yusuf, 2016) bahwa proses pelaksanaan program pengabdian dalam bentuk workshop dengan orientasi praktik dan workshop dengan mengedepankan prinsip partnership yang amenjadikan proses berlangsung interaktif dan dinamis berkembang secara konstrukti

Selain menyampaikan materi, pemateri juga membimbing peserta dalam pembuatan e-modul nya. Modul yang dijadidikan e-modul adalah modul yang sudah dikerjakan sebelumnya, sehingga materi 
modul dalam bentuk dokumen ke bentuk elektronik modul (e-modul) dan materi bisa di buka pada HP Android. Berkenaan dengan e-modul maka guru matematika SMK diharapkan kreatif membuat emodul dan mampu mengembangkan materi-materi matematika agar e-modul menarik bagi peserta didik. Hal ini sesuai dengan pendapat pendapat (Husain, 2014), bahwa upaya untuk mengoptimalkan pemanfaatan teknologi informasi dan komunikasi dalam pembelajaran adalah memberikan motivasi kepada para guru berkenaan dengan pemanfaatan teknologi informasi dan komunikasi dalam pembelajaran serta berbagai pelatihan dan workshop baik yang diselenggarakan oleh pihak sekolah secara mandiri maupun dari pihak luar sekolah.

Hasil yang dicapai dalam pelaksanaa program kemitraan masyarakat pada pelatihan IT melalui pembuatan e-modul guru matematika SMK kabupaten Malang yaitu peningkatan pemahaman membuat modul matematika. Hal ini tampak pada kreatifitas guru matematika dalam pembuatan modul matematika. Modul yang dihasilkan diantaranya tampak pada gambar berikut

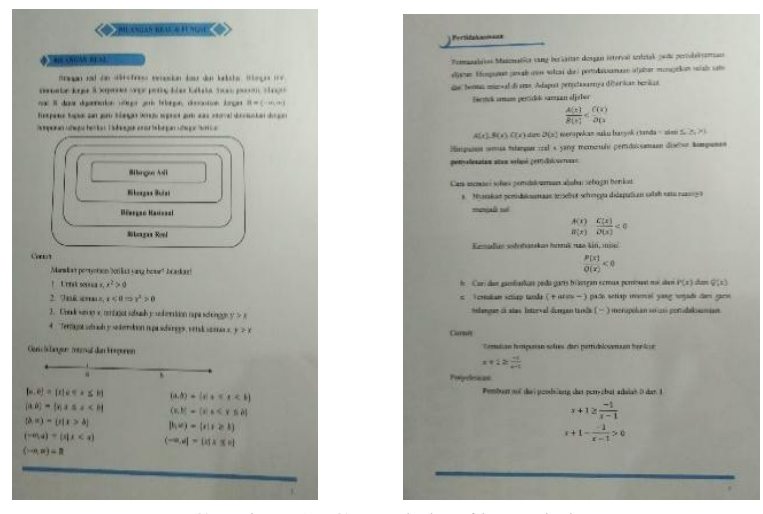

Gambar 1. Contoh hasil modul

Ketercapaian peningkatan pemahaman guru SMK dalam pembuatan modul diharapkan berpengaruh terhadap peningkatan kualitas guru dalam pembelajaran. Guru harus kreatif dalam pembelajaran agar selaras dengan tuntutan pada kurikulum.

Selain itu peningkatan pemahaman membuat modul matematika, hasil yang dicapai dalam pelaksanaa program kemitraan masyarakat pada pelatihan IT melalui pembuatan e-modul guru matematika SMK kabupaten Malang yaitu peningkatan pemahaman membuat e-modul matematika dengan langkah-langkah e-modul pada HP Android yang menggunakan aplikasi sigil. Hal ini tampak pada keberhasilan mengubah file modul dalam word menjadi file modul dalam Electronic Publication (Epub) yang berupa file html dan selanjutnya menggunakan aplikasi sigil. Hasil emodul bisa dibaca melalui HP Android dengan aplikasi software ireader. Pada langkah pertama dan kedua menggunakan software pengolahan kata/Ms Word. Selanjutnya pada langkah ketiga menggunakan software sigil yang tampak gambar berikut:

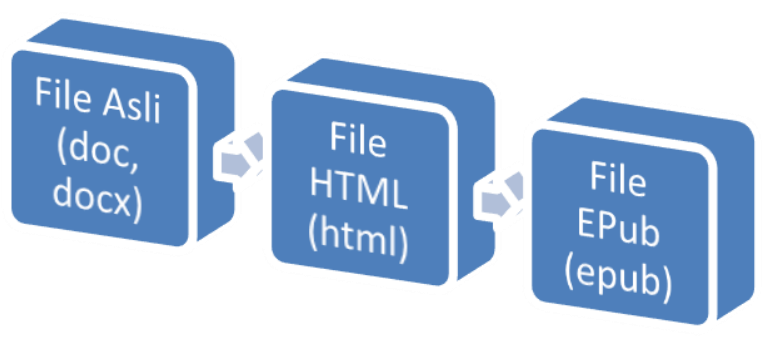

Gambar 2. Proses digital e-modul

Hasil yang dicapai dalam pelaksanaa program kemitraan masyarakat pada pelatihan IT melalui pembuatan e-modul guru matematika SMK kabupaten Malang yang berikutnya yaitu respon yang positif pada pelaksanaan desiminasi hasil pembuatan modul dan e-modul. Respon tanggapan yang positif dari guru matematika SMK Kabupaten Malang sangat membatu dalam suksesnya kegiatan program kemitraan masyarakat.

Pembuatan modul dan e-modul merupakan salah satu ketrampilan guru dalam pembelajaran dengan mengguanakan teknologi. Pembelajaran dengan menggunakan teknologi sangat berperan dalam upaya meningkatkan kualitas pendidikan. Guru sebagai tenaga pendidik harus melakukan inovasi dalam pembelajaran. Hal ini sesuai dengan pendapat (Fitriyadi, 2012; Munir, 2009) yang menyatakan bahwa guru sebagai aktor utama dalam proses pendidikan dituntut harus dengan cepat memperbaharui pengetahuan, keterampilan, dan kompetensinya dalam bidang Teknologi Informasi dan Komunikasi (TIK), tak terkecuali guru produktif Sekolah Menengah Kejuruan (SMK)

Hasil modul matematika dan e-modul matematika yang dihasilkan guru matematika SMK Kabupaten Malang sangat bermanfaat dalam 
meningkatkan pembelajaran matematika SMK, terutama peserta didik yang melaksanakan prakerin. Peserta didik yang prakerin saling berinteraksi dengan pembelajaran menggunakan modul dan emodul sehingga pembelajaran lebih efektif.

\section{KESIMPULAN}

Kegiatan program kemitraan masyarakat pada pelatihan IT melalui pembuatan e-modul dapat meningkatkan pemahaman guru matematika dalam pembelajaran dengan menggunakan aplikasi sigil dan mendapat respon yang positif dari guru matematika SMK. Produk yang dihasilkan dalam kegiatan program kemitraan masyarakat berupa modul dan e-modul matematika. Pelatihan dalam bidang IT bagi guru matematika SMK perlu dikembangkan dengan menggunakan aplikasi software lainnya agar guru matematika SMK lebih trampil dalam pembelajaran matematika menggunakan teknologi.

\section{REFERENSI}

Fitriyadi, H. (2012). Ketrampilan TIK guru Produktif SMK di Kabupaten Hulu Sungai Utara dan Implementasi dalam Pembelajaran, Jurnal Pendidikan Vokasi, 2, (2), 213-233.

Husain, C. (2014). Pemanfaatan Teknologi Informasi dan Komunikasi dalam Pembelajaran di SMA Muhammadiyah Tarakan. Jurnal Kebijakan Dan Pengembangan Pendidikan, 2(2), 184-192.

Kemendikbud. (2013). Diklat Guru dalam Rangka Implementasi Kurikulum 2013. Jakarta: BSNP.

Mahmud, I. (2013). Musyawarah Guru Mata Pelajaran (MGMP) Sejarah untuk Meningkatkan Profesionalisme Guru SMA di Kota Batu. http://karyailmiah.um.ac.id/index.php/sejarah/article/view/ 23807

Munir. (2009). Kontribusi Teknologi Informasi dan Komunikasi (TIK) dalam Pendidikan Di Era Globalisasi Pendidikan Indonesia. Jurnal Pendidikan Teknologi Informasi Dan Komunikasi (PTIK). 2, (2), 1-4.

Zuriah, N., Sunaryo, H., \& Yusuf, N. (2016). IbM Guru dalam Pengembangan Bahan Ajar Kreatif Inovatif Berbasis Potensi Lokal. Jurnal Dedikasi, 13, 39-49. 